\title{
Article \\ Effect of Polythiophene Content on Thermomechanical
Properties of Electroconductive Composites
}

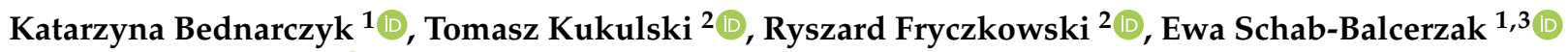 \\ and Marcin Libera ${ }^{1, *(1)}$ \\ 1 Institute of Chemistry, University of Silesia in Katowice, 9 Szkolna Str., 40-006 Katowice, Poland; \\ kbednarczyk@us.edu.pl (K.B.); ewa.schab-balcerzak@us.edu.pl (E.S.-B.) \\ 2 Faculty of Materials, Civil and Environmental Engineering, University of Bielsko-Biala, Willowa 2 Str., \\ 43-309 Bielsko-Biala, Poland; tkukulski@ath.bielsko.pl (T.K.); rfryczkowski@ath.bielsko.pl (R.F.) \\ 3 Centre of Polymer and Carbon Materials, Polish Academy of Sciences, 34 M. Curie-Sklodowskej Str., \\ 41-819 Zabrze, Poland \\ * Correspondence: marcin.libera@us.edu.pl; Tel.: +48-50-518-7647
}

\section{check for} updates

Citation: Bednarczyk, K.; Kukulski, T.; Fryczkowski, R.; Schab-Balcerzak, E.; Libera, M. Effect of Polythiophene Content on Thermomechanical Properties of Electroconductive Composites. Molecules 2021, 26, 2476. https: / / doi.org/10.3390/

molecules 26092476

Academic Editors:

Matthias Schnabelrauch and Jadwiga Sołoducho

Received: 20 March 2021

Accepted: 20 April 2021

Published: 23 April 2021

Publisher's Note: MDPI stays neutral with regard to jurisdictional claims in published maps and institutional affiliations.

Copyright: (c) 2021 by the authors. Licensee MDPI, Basel, Switzerland. This article is an open access article distributed under the terms and conditions of the Creative Commons Attribution (CC BY) license (https:// creativecommons.org/licenses/by/ $4.0 /)$.

\begin{abstract}
The thermal, mechanical and electrical properties of polymeric composites combined using polythiophene (PT) dopped by $\mathrm{FeCl}_{3}$ and polyamide 6 (PA), in the aspect of conductive constructive elements for organic solar cells, depend on the molecular structure and morphology of materials as well as the method of preparing the species. This study was focused on disclosing the impact of the polythiophene content on properties of electrospun fibers. The elements for investigation were prepared using electrospinning applying two substrates. The study revealed the impact of the substrate on the conductive properties of composites. In this study composites exhibited good thermal stability, with $\mathrm{T}_{5}$ values in the range of $230-268{ }^{\circ} \mathrm{C}$ that increased with increasing PT content. The prepared composites exhibited comparable PA $\mathrm{T}_{\mathrm{g}}$ values, which indicates their suitability for processing. Instrumental analysis of polymers and composites was carried out using Fourier Transform Infrared spectroscopy (FT-IR), thermogravimetric analysis (TGA), differential scanning calorimetry (DSC), dynamic mechanical thermal analysis (DMTA) and scanning electron microscopy (SEM).
\end{abstract}

Keywords: composites; electrospinning; conducting polymer; polythiophene; morphology; thermomechanical analysis

\section{Introduction}

Electroconductive composites, due to their ability to form elastic constructive materials, are of major scientific and research interest with respect to their utilization for innovative solar cells, detectors or diodes [1,2]. Electrospinning of such composites an area of investigation due to the possible implication to produce elements such as photonic devices, among others [3-7].

Third-generation photovoltaics is one of the many areas of application for PT composite nanofibers. This polymer is an attractive alternative to the platinum counter electrode for dye-sensitized solar cells (DSSCs) due to its low cost, easy production, environmental friendliness, temperature stability and relatively high conversion efficiency. To date, many DSSCs in which the counter electrode was made of PT in different forms have been investigated [8].

The thiophene monomer can be polymerized by chemical or electrochemical methods [9]. First, polythiophene is generated by a metal-catalyzed polycondensation of 2,5-dibromothiophene [10]. Such a method leads to insoluble oligomers of molar mass below $3000 \mathrm{~g} / \mathrm{mol}$. One of the most often applied polymerizations of unsubstituted thiophene is synthesis with $\mathrm{FeCl} 3$ conducted in chloroform (Figure 1) [11], as also termed "classic". The desirability of such a synthesis method is its unreproductivity, meaning that the same 
conditions of polymerization can result in different polymers (molar masses and its dispersion). Despite the limited processability of polythiophene made by the "classic" method of synthesis, they are still exploited to generate material for investigation of composites and films, among others.

Standard DSSCs consist of a working electrode (WE/photoanode), liquid electrolyte and counter electrode ( $\mathrm{CE}$ /photocathode). As an alternative to conventional electrode materials, conductive nanocomposites composed of conducting nanomaterials and elastomeric media have been extensively studied for use in stretchable interconnections and devices. These stretchable conductive nanocomposites consist of percolation networks of nanoscale conductive fillers in elastomeric matrixes.

The usefulness of composite materials for advanced applications such as third-generation photovoltaics depends on the morphology and mechanical properties of the prepared elements, among others.

The formation of materials made of composites of PT in the form of fibers and nanofibers can lead to more efficient solar cells [12] and is essential in the production of flexible and wearable devices [13]. In particular, the development of PT nanofibers has significant benefits in comparison with film-casting polymers, as the former technique leads to a highly active surface area.

Electrospinning is one of the preparation methods for ultrathin fibers that have much smaller diameters than those obtained with conventional techniques [14]. Furthermore, by electrospinning, it is possible to adjust the properties of materials (e.g., fibers alignment, porosity and inner fiber structuration) [15]. The strong stretching forces and the physical confinement into the cylindrical fibers generated by electrospinning strongly affect the orientation of polymer chains along the long axis of a fiber [16]. Additional consequences of electrospinning of composites can be distinguished, taking into consideration the base layer applied for processing. Therefore, processing PT composites using electrospinning generates materials with new features [17].

The viscoelastic, thermal, morphological and conductive properties of materials induced by content of fillers in fibers, which creates thin mats made by electrospinning of conductive composites, can be revealed by correlative investigations of thermogravimetric, differential scanning, calorimetric and dynamic mechanical thermal analyses together with light scattering as well as electron microscopic observation. The storage modulus $\left(\mathrm{E}^{\prime}\right)$ and the loss modulus ( $\left.\mathrm{E}^{\prime \prime}\right)$ are of major interest to determine, respectively, the elastic, viscous and damping properties of materials as well as the relationship of such properties with the structure and morphology of composite materials.

The present study focused on disclosing the impact of PT particles having a defined shape factor on the properties of composites composed of PT and polyamide (PA6). Herein, the base layer applied for electrospinning of mats will also be presented to expose the importance of such a factor. The results show that the properties of composite mats made of the same materials depend strongly not only on the content of fillers but also on the base layer applied for preparation, which should be taken under consideration during utilitarian functions.

\section{Results}

The syntheses of polythiophene in chloroform using ferric chloride as an oxidant yielded dark-brown powders. A scheme of oxidative polymerization is presented in Figure 1. After filtration, the powder was dried in a $60^{\circ} \mathrm{C}$ oven under reduced pressure for $12 \mathrm{~h}$ and stored under an ambient atmosphere. The reaction yield after filtration was $84 \%$. 


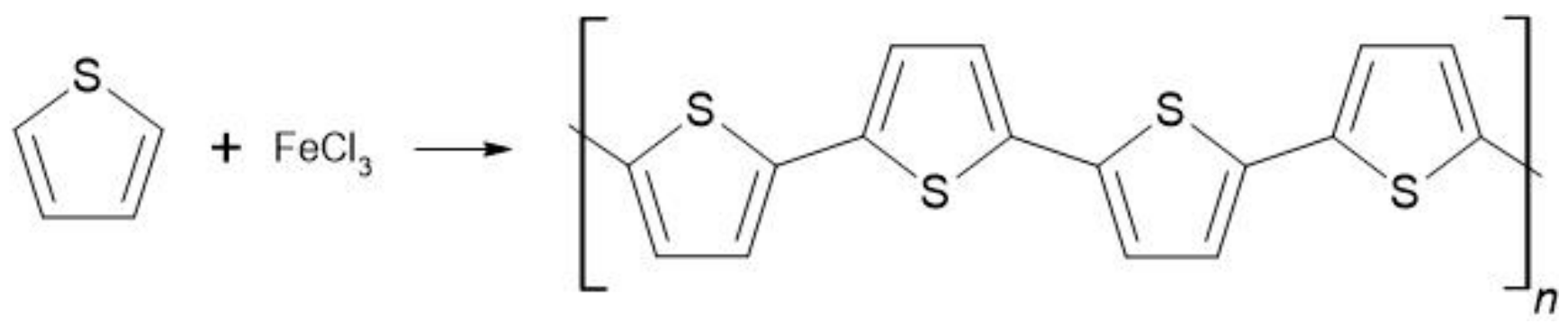

Figure 1. Scheme of oxidative polymerization of thiophene.

Polythiophene was used to prepare composites with polyamide. The composites were prepared via electrospinning. Electrospinning conditions were selected based on the trial-and-error method. The composites were diversified by the polythiophene composite content and substrate type, and the data are collected in Table 1 . The authors prepared materials by the electrospinning method, taking under consideration the flexibility and plasticity of the obtained composites. Electrospinning is known also as a method for improving the mechanical properties of composite films [18-21].

Table 1. Data taken to prepare composite films.

\begin{tabular}{|c|c|c|c|}
\hline Name & Substrate & Polythiophene (g) & Polythiophene (\%) \\
\hline PAPT1Al & \multirow{7}{*}{ aluminum } & 1.53 & $5 \%$ \\
\hline PAPT2Al & & 0.92 & $3 \%$ \\
\hline PAPT3Al & & 0.61 & $2 \%$ \\
\hline PAPT4Al & & 0.26 & $0.85 \%$ \\
\hline PAPT5Al & & 0.153 & $0.5 \%$ \\
\hline PAPT6Al & & 0.0765 & $0.25 \%$ \\
\hline PAPT7Al & & 0.0153 & $0.05 \%$ \\
\hline PAPT1Ag & \multirow{7}{*}{ silver } & 1.53 & $5 \%$ \\
\hline PAPT2Ag & & 0.92 & $3 \%$ \\
\hline PAPT3Ag & & 0.61 & $2 \%$ \\
\hline PAPT4Ag & & 0.26 & $0.85 \%$ \\
\hline PAPT5Ag & & 0.153 & $0.5 \%$ \\
\hline PAPT6Ag & & 0.0765 & 0.25 \\
\hline PAPT7Ag & & 0.0153 & $0.05 \%$ \\
\hline
\end{tabular}

Polythiophene structure after synthesis was analyzed with FTIR studies at room temperature. The representative analysis of PAPT1Al is listed above. The results showed a characteristic absorption band at $1540 \mathrm{~cm}^{-1}$, which corresponds to $C=C$ stretching vibration from the thiophene ring. C-C bonds were visible at $840 \mathrm{~cm}^{-1}$ and $1223 \mathrm{~cm}^{-1}$, which correspond to bending vibrations and stretching vibrations, respectively. The absorption peak at $758 \mathrm{~cm}^{-1}$ corresponded with stretching vibrations of the $\mathrm{C}-\mathrm{H}$ bond. The C-S out-of-plane deformation bond vibrations were visible at $709 \mathrm{~cm}^{-1}$. The results confirmed the structure of polyaniline presented in the literature [22-24].

The thermal properties of polythiophene, polyamide and the thermomechanical properties of the manufactured composites were analyzed using TGA, DSC and DMTA measurements. Thermal stability was characterized by the temperatures at which 5\% (T5) or $10 \%$ (T10) weight loss occurred, which was defined as the temperature at the beginning of thermal decomposition, and by the temperatures at the maximum rate of compound degradation (Tmax), which were determined from differential thermogravimetric analysis (DTA). The glass transition temperature (Tg) was characterized using DSC and DMTA measurements. The results obtained from thermal measurements are collected in Table 2. The TGA and DMTA graphs are shown in Figure 2. 
Table 2. Thermal properties of starting polymers and conductive composites.

\begin{tabular}{|c|c|c|c|c|c|c|c|}
\hline Sample & $\mathrm{T}_{5}\left({ }^{\circ} \mathrm{C}\right)$ & $\mathrm{T}_{10}\left({ }^{\circ} \mathrm{C}\right)$ & Residue at $900{ }^{\circ} \mathrm{C}(\%)$ & $\mathrm{T}_{\max }\left({ }^{\circ} \mathrm{C}\right)$ & $\mathrm{T}_{\mathrm{gDSC}}\left({ }^{\circ} \mathrm{C}\right)$ & $\mathrm{T}_{\mathrm{mDSC}}\left({ }^{\circ} \mathrm{C}\right)$ & $\mathrm{T}_{\text {gDMTA }}\left({ }^{\circ} \mathrm{C}\right)$ \\
\hline Polythiophene & 283 & 315 & 2.6 & $73 ; 483$ & 60 & 204 & - \\
\hline Polyamide & 325 & 430 & 1.8 & 461 & 52 & 228 & - \\
\hline PAPT1Al & 226 & 410 & 1.9 & $50 ; 475$ & 61 & 218 & 60 \\
\hline PAPT2Al & 254 & 414 & 0.6 & $76 ; 472$ & 58 & 220 & 58 \\
\hline PAPT3Al & 266 & 414 & 0.1 & $73 ; 469$ & 57 & 218 & 58 \\
\hline PAPT4Al & 273 & 415 & 0.6 & $72 ; 469$ & 55 & 218 & 57 \\
\hline PAPT5Al & 272 & 416 & 0.3 & $78 ; 467$ & 55 & 217 & 54 \\
\hline PAPT6Al & 270 & 415 & 0.3 & $65 ; 465$ & 54 & 217 & 54 \\
\hline PAPT7Al & 285 & 419 & 0.4 & $75 ; 464$ & 54 & 215 & 48 \\
\hline PAPT1Ag & 228 & 409 & 1.4 & $45 ; 475$ & 58 & 222 & 66 \\
\hline PAPT2Ag & 240 & 410 & 0.5 & $78 ; 473$ & 58 & 221 & 62 \\
\hline PAPT3Ag & 267 & 412 & 0.2 & $43 ; 469$ & 57 & 220 & 59 \\
\hline PAPT4Ag & 271 & 414 & 0.3 & $73 ; 467$ & 56 & 219 & 58 \\
\hline PAPT5Ag & 272 & 414 & 0.4 & $47 ; 463$ & 54 & 217 & 54 \\
\hline PAPT6Ag & 275 & 415 & 0.1 & $48 ; 463$ & 54 & 216 & 51 \\
\hline PAPT7Ag & 276 & 415 & 0.2 & $60 ; 462$ & 53 & 216 & 49 \\
\hline
\end{tabular}

T5 and T10 represent the temperatures of 5 and 10\% weight loss. Tmax is the temperature of the maximum decomposition rate as determined by DTA. TgDSC is the glass transition temperature by DSC, and TgDMTA is the glass transition temperature by DMTA. TmDSC is the melting temperature by DSC.

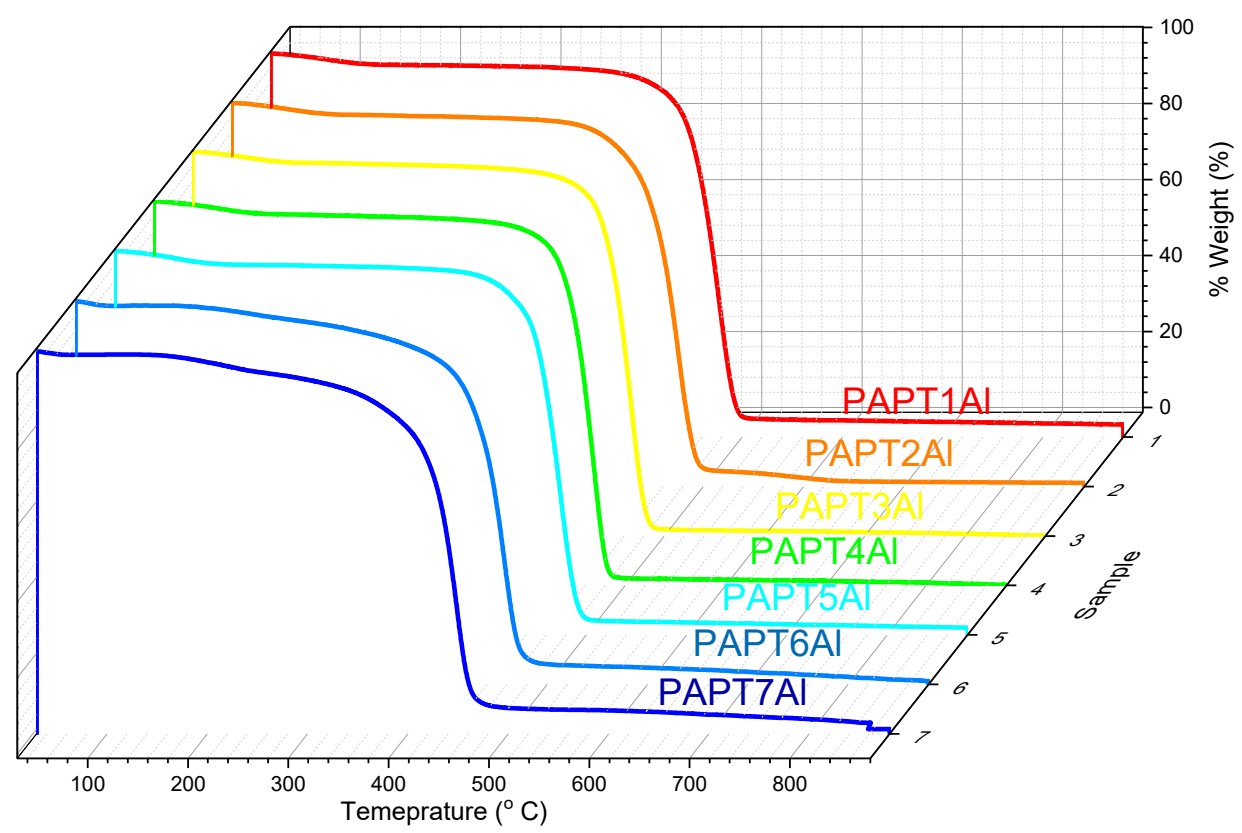

Figure 2. Thermogravimetric thermographs of composites.

The TGA thermographs of polythiophene confirmed the pure polymer preparation. TGA thermograph showed a two-step degradation process, where the first step of degradation visible in the peak at $73{ }^{\circ} \mathrm{C}$ corresponded with solvent evaporation, remaining after the synthesis. The second step of degradation visible on the DTA graph at $483^{\circ} \mathrm{C}$ indicated thermal depolymerization of the polymer, as reported previously [25]. The T10 temperature, which represents the thermal stability of polymer, for polythiophene occurred at $315^{\circ} \mathrm{C}$. Polyamide showed a one-step degradation process; the polymer was stable until $430^{\circ} \mathrm{C}$ (T10). The thermal degradation of polyamide, which occurred on the DTA graph at $467^{\circ} \mathrm{C}$, is also reported at literature [26,27].

TGA thermographs of the composites are presented in Figure 2 and indicate that the composites had better thermal stability (verify by Tmax) than polythiophene but were worse than polyamide used in their preparation. The results confirmed that PT content 
determined the thermal stability of composites, and they indicate substrate consequences in the context of the manufacturing method. Increase in PT concentration elevated the Tmax of composites. All composites showed a two-step degradation process. The first weight loss for composites was attributed to the evaporation of solvent and was visible for all composites in the temperature range between 43 and $78{ }^{\circ} \mathrm{C}$. The second weight loss was attributed to degradation of composite and occurred between 462 and $475{ }^{\circ} \mathrm{C}$. The second weight loss for PAPT1Al, which contains the biggest amount PT, occurred at $475{ }^{\circ} \mathrm{C}$, for PAPT2Al at $472{ }^{\circ} \mathrm{C}$ and for PAPT3Al and PAPT4Al at $469^{\circ} \mathrm{C}$. For PAPT7Al, which contained the smallest amount of PT, the weight loss occurred at $464{ }^{\circ} \mathrm{C}$. The second weight losses for composites spun with the silver substrate were visible as follows: PAPT1Ag at $475{ }^{\circ} \mathrm{C}$, PAPT2Ag at $473{ }^{\circ} \mathrm{C}$, PAPT3Ag at $469^{\circ} \mathrm{C}$, PAPT4Ag at $467{ }^{\circ} \mathrm{C}$ and PAPT7Ag at $462^{\circ} \mathrm{C}$. In general, the thermographs showed that the composite with the most PT had the highest degradation temperature and showed the best thermal stability. Composites with $5 \%$ PT showed the same temperature for the second thermal degradation step both for the aluminum and silver substrate. The composites containing 0.5\% PT (PAPT5Al and PAPT5Ag) showed thermal degradation peaks at 467 and $463^{\circ} \mathrm{C}$, respectively. The composites containing $0.05 \%$ PT (PAPT5Al and PAPT5Ag) showed thermal degradation peaks at 464 and $462{ }^{\circ} \mathrm{C}$, respectively. The differences in degradation temperature between composites prepared on aluminum and silver substrates were negligible. The biggest difference was $4{ }^{\circ} \mathrm{C}$ between PAPT5Al and PAPT5Ag composites. The T5 temperature of all composites was in the range of 226 to $285^{\circ} \mathrm{C}$. The T10 temperature of composites was in the range of $409-416^{\circ} \mathrm{C}$. The T5 and T10 temperatures changed with PT concentration in the composite. The T5 and T10 temperatures decreased with increasing PT content in composites. The T5 temperatures were $226^{\circ} \mathrm{C}$ for PAPT1Al and $228^{\circ} \mathrm{C}$ for PAPT1 Ag, and the T10 temperatures were $409^{\circ} \mathrm{C}$ for PAPT1Al and $410{ }^{\circ} \mathrm{C}$ for PAPT1Ag. The T5 and T10 temperatures were similar for both composites made on aluminum and silver substrates. The final residue after thermal degradation was in the range of $1.9 \%$ and $0.1 \%$ of the initial weight and was the biggest for composites containing $5 \%$ PT.

Glass transition temperatures of polymers and composites are shown in Table 2. The $\mathrm{Tg}$ of polythiophene occurred at $60^{\circ} \mathrm{C}$ and of polyamide at $52{ }^{\circ} \mathrm{C}$. Tm for polythiophene occurred at $204^{\circ} \mathrm{C}$ and for polyamide at $228^{\circ} \mathrm{C}$. The $\mathrm{Tg}$ and $\mathrm{Tm}$ for polymers were determined by the DSC method. The results correspond with the literature [28]. Composite glass and melting transition temperatures were determined by DSC and DMTA methods. The DSC thermographs of composites are showed at Figure 3 and exhibit an endothermic peak in the range of $30-90{ }^{\circ} \mathrm{C}$, which occurred during the first scan due to solvent evaporation. The solvent evaporation was also observed in the TGA thermographs. The second DSC peak of composites appeared in the range of 53-61 ${ }^{\circ} \mathrm{C}$ and was related with the glass transition temperature of composites. The third DSC peak appeared in the range of $215-222^{\circ} \mathrm{C}$ and was related with melting temperature of composites. Tg obtained for composites with the DMTA method appeared in the range of $48-66^{\circ} \mathrm{C}$. The DMTA glass transition temperature values were higher than the values obtained with the DSC method. Differences between the two methods were common, as the exact position of Tg depends on the frequency used in DMTA, whereas in DSC it depends on the heating rate used [29]. In this study, the DSC heating rate was $20^{\circ} \mathrm{C} / \mathrm{min}$, whereas the DMTA heating rate was $3{ }^{\circ} \mathrm{C} / \mathrm{min}$. Tg measured with DSC for composites were as follows: $61^{\circ} \mathrm{C}$ for PAPT1Al, $58^{\circ} \mathrm{C}$ for PAPT2Al, $57{ }^{\circ} \mathrm{C}$ for PAPT3Al and $55{ }^{\circ} \mathrm{C}$ for PAPT4Al. For composites prepared on silver substrates: $58{ }^{\circ} \mathrm{C}$ for PAPT1Ag, $58{ }^{\circ} \mathrm{C}$ for PAPT2Ag, $57^{\circ} \mathrm{C}$ for PAPT3Ag and $56^{\circ} \mathrm{C}$ for PAPT4Ag. The differences between composites containing various amounts of PT were clearly seen. The biggest $\mathrm{Tg}$ was found for the composite with $5 \% \mathrm{PT}$ and the smallest with $0.05 \%$ PT. Such dependency was real both for composites made on aluminum and silver substrates. Composite Tg values measured with DMTA were $60^{\circ} \mathrm{C}$ for PAPT1Al, $58{ }^{\circ} \mathrm{C}$ for PAPT2Al, $58^{\circ} \mathrm{C}$ for PAPT3Al and $57^{\circ} \mathrm{C}$ for PAPT4Al. As we could see, the glass temperature was related with the polythiophene content in the composite and was higher with higher PT concentration in composite. For composites prepared with silver substrates 
the values were $66^{\circ} \mathrm{C}$ for PAPT1Ag, $62{ }^{\circ} \mathrm{C}$ for PAPT2Ag, $59{ }^{\circ} \mathrm{C}$ for PAPT3Ag and $58{ }^{\circ} \mathrm{C}$ for PAPT4Ag. The dependency of Pt amount in the composite was similar for aluminum substrate composites: the higher the concentration of $\mathrm{PT}$ in the composite, the higher the $\mathrm{Tg}$ value. The difference between $\mathrm{Tg}$ for PAPT1Al obtained with the DSC and DMTA methods was $1{ }^{\circ} \mathrm{C}$, for PAPT2Al $0{ }^{\circ} \mathrm{C}$ and for PAPT3Al $1{ }^{\circ} \mathrm{C}$. The melting transition temperature of polymers and composites is shown in Table 2 . Tm obtained for composites with the DSC method appeared in the range of $215-222^{\circ} \mathrm{C}$. Tm values measured for composites were as follows: $218{ }^{\circ} \mathrm{C}$ for PAPT1Al, $220^{\circ} \mathrm{C}$ for PAPT2Al, $220^{\circ} \mathrm{C}$ for PAPT3Al and $218^{\circ} \mathrm{C}$ for PAPT4Al. For composites prepared on silver substrates: $222^{\circ} \mathrm{C}$ for PAPT1Ag, $221{ }^{\circ} \mathrm{C}$ for PAPT2Ag, $220^{\circ} \mathrm{C}$ for PAPT3Ag and $219^{\circ} \mathrm{C}$ for PAPT4Ag. The biggest Tm was found for the composite containing 5\% PT and the smallest with $0.05 \%$ PT. Such dependency was real both for composites made on aluminum and silver substrates. The dependency of PT amount in the composite was similar as for dependency of glass transition temperature for composites. The melting temperature decreased with decreasing PT concentration.
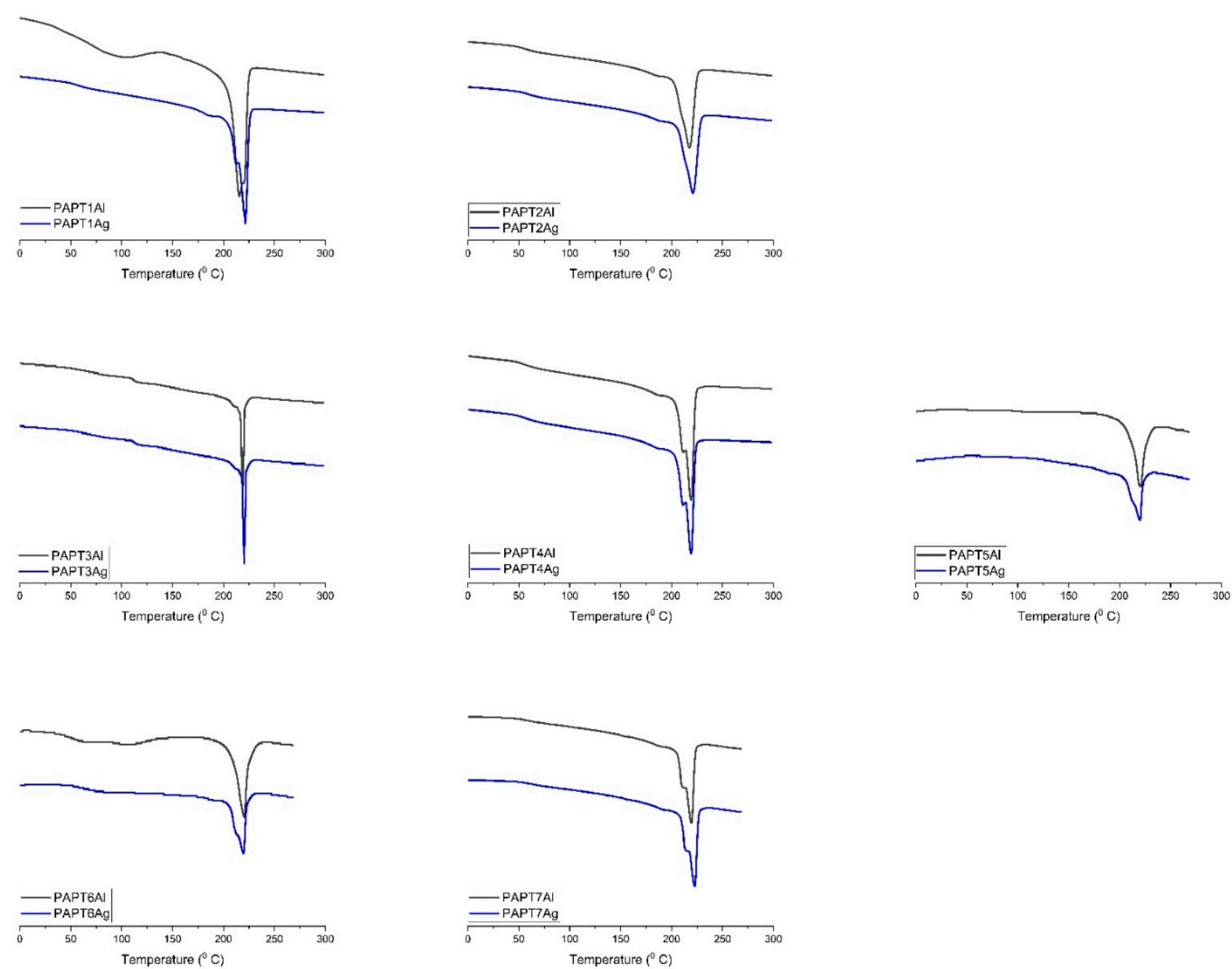

Figure 3. Differential scanning calorimetry of composites.

The mechanical characterization of composites was performed in dual cantilever mode in the temperature range of $-80^{\circ} \mathrm{C}$ to $220^{\circ} \mathrm{C}$ at a heating rate of $3{ }^{\circ} \mathrm{C} / \mathrm{min}$ and frequency of $1 \mathrm{~Hz}$. The dimensions of the samples were $35.0 \times 10.2 \times 1.0 \mathrm{~mm}$. Figure 2 shows the variations in the loss modulus, storage modulus and tangent $\delta$ of the representative material.

Table 3 and Figure 4 show the relationship of the storage and loss modulus of the composites versus the temperature. There were two peaks visible for storage, loss modulus 
and tangent delta $(\tan \delta)$. The storage modulus peaks were visible between 20 and $70{ }^{\circ} \mathrm{C}$ for region $(\alpha)$ and between -10 and $20^{\circ} \mathrm{C}$ for region $(\beta)$. The $\alpha$ relaxation is the mechanical manifestation of the glass transition temperature. The $\beta$ relaxation was almost the same for all composites independently from PT concentration. This temperature transition is known to be related to thiophene ring motions within the chains, which were very similar for the polyamide and polythiophene in the composites. Increasing the temperature led to decreasing the composite storage modulus. Similarly to the storage modulus above the peak maximum, the loss modulus started to decrease while the temperature of the process increased. The tangent $\delta$ values for samples were represented by one peak between 20 and $75^{\circ} \mathrm{C}$, which is in agreement with others for glass transition temperature of tested composites. The values of DMTA measurements agreed with literature studies [30]. The DMTA results were dependent on the substrate used and PT content. $\mathrm{E}^{\prime}$ values are listed above, for PAPT1Al as well as PAPT1Ag, which at $-10{ }^{\circ} \mathrm{C}$ were 3.2 and $2.9 \mathrm{GPa}$, respectively; at $20^{\circ} \mathrm{C}, 4.0$ and $3.5 \mathrm{GPa}$ for PAPT1Al and PAPT1Ag, respectively; and for $70{ }^{\circ} \mathrm{C}$ the values were 2.0 and $1.6 \mathrm{GPa}$. $\mathrm{E}^{\prime}$ at $20^{\circ} \mathrm{C}$ for PAPT2Al was equal to $3.8 \mathrm{GPa}$ and for PAPT2Ag 3.5 GPa, for PAPT3Al 3.5 GPa and for PAPT3Ag 2.6 GPa, for PAPT4Al 2.5 GPa and for PAPT4Ag 1.8 GPa, for PAPT5Al 1.8 GPa and for PAPT5Ag 1.5 GPa, for PAPT6Al 1.5 GPa and for PAPT6Ag 1.5 GPa, for PAPT7Al 1.4 GPa and for PAPT7Ag 1.4 GPa. Comparing the $\mathrm{E}^{\prime}$ values at one temperature, one can say that the silver substrate resulted in lower $\mathrm{E}^{\prime}$ values. The results were lower in range of 0-0.9 GPa. The differences were clearly seen for composites with varied PT concentrations. The results taken from one substrate and different content of PT show that increasing the PT concentration in the composite resulted in higher $\mathrm{E}^{\prime}$. This indicates that the composite with $5 \%$ of PT was the most stiff. The same dependency was seen with $E^{\prime \prime}$ values, which are listed in Table 3. Increasing the concentration of PT in composite resulted in higher E" values. This means that the composites with higher PT amounts showed more material resistance.

Table 3. Storage and loss modulus versus temperature of composites.

\begin{tabular}{ccccccc}
\hline \multirow{2}{*}{ Name } & \multicolumn{3}{c}{$\mathbf{E}^{\prime} \mathbf{( G P a )}$} & \multicolumn{3}{c}{$\mathbf{E}^{\prime \prime}(\mathbf{G P a})$} \\
\cline { 2 - 6 } & $-\mathbf{1 0}{ }^{\circ} \mathbf{C}$ & $\mathbf{2 0}{ }^{\circ} \mathbf{C}$ & $\mathbf{7 0}^{\circ} \mathbf{C}$ & $-\mathbf{1 0}{ }^{\circ} \mathbf{C}$ & $\mathbf{2 0}^{\circ} \mathbf{C}$ & $\mathbf{7 0}^{\circ} \mathbf{C}$ \\
\hline PAPT1Al & 3.2 & 4.0 & 2.0 & 1.7 & 3.1 & 0.7 \\
PAPT2Al & 3.1 & 3.8 & 2.1 & 1.6 & 2.3 & 0.2 \\
PAPT3Al & 2.9 & 3.5 & 1.8 & 1.5 & 1.6 & 0.1 \\
PAPT4Al & 2.3 & 2.5 & 1.3 & 1.2 & 1.3 & 0.1 \\
PAPT5A1 & 2.2 & 1.8 & 1.0 & 0.9 & 1.1 & 0.3 \\
PAPT6Al & 2.0 & 1.5 & 1.0 & 0.8 & 1.1 & 0.2 \\
PAPT7Al & 2.0 & 1.4 & 1.0 & 0.8 & 1.0 & 0.2 \\
PAPT1Ag & 2.9 & 3.5 & 1.6 & 1.8 & 3.2 & 1.0 \\
PAPT2Ag & 2.8 & 3.5 & 1.4 & 1.7 & 3.0 & 0.8 \\
PAPT3Ag & 2.2 & 2.6 & 1.3 & 1.6 & 2.8 & 0.3 \\
PAPT4Ag & 2.2 & 1.8 & 1.2 & 1.6 & 1.9 & 0.1 \\
PAPT5Ag & 2.0 & 1.5 & 1.0 & 1.4 & 1.6 & 0.1 \\
PAPT6Ag & 2.0 & 1.4 & 1.0 & 1.2 & 1.4 & 0.2 \\
PAPT7Ag & 1.9 & 1.4 & 0.9 & 1.2 & 1.3 & 0.2 \\
\hline
\end{tabular}



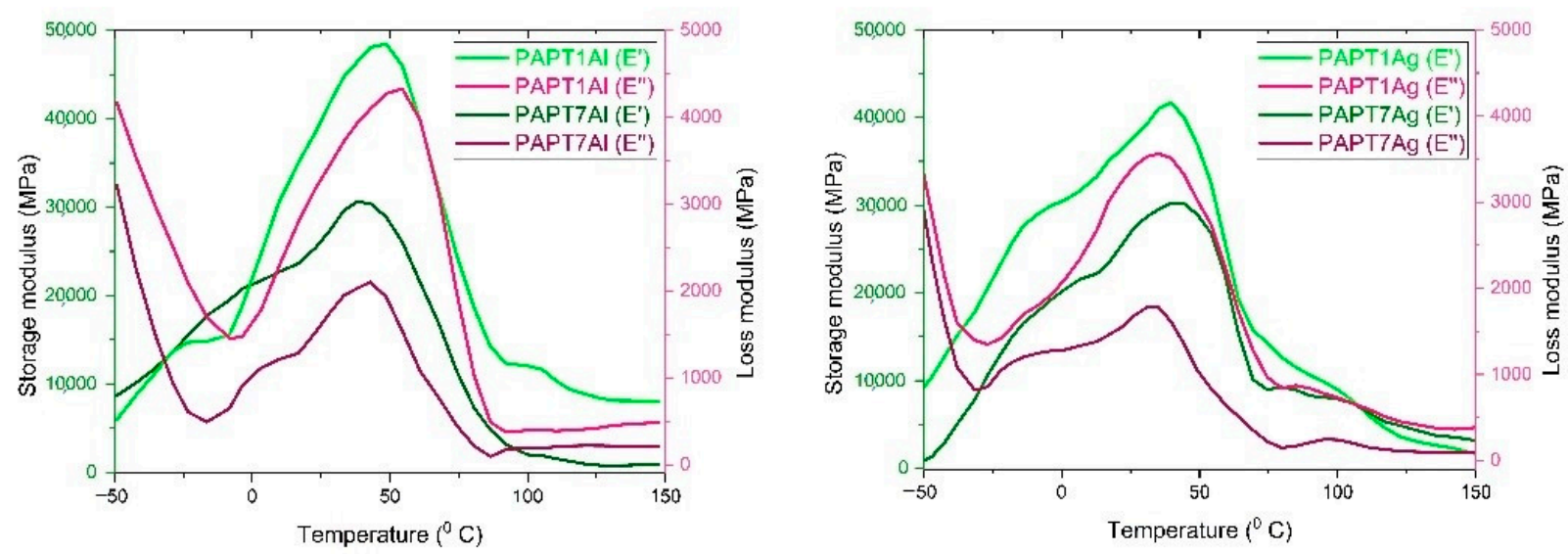

Figure 4. Dynamic mechanical thermal analysis of PAPT1Al, PAPT1Ag, PAPT7Al and PAPT7Ag composites.

The results of conductivity based on resistivity measurements are given in Table 4 . Resistivity was measured up to $200 \mathrm{ohm}$, and higher results were noted as no results. The measurements were repeated 15 times on each sample, and the electrodes were applied in the same distance of $1 \mathrm{~cm}$. The conductivity of the prepared composites was dependent on the PT content and substrate used for preparing the composite. The composite mats prepared on aluminum exhibited conductivity for samples with 5, 3 and $2 \%$ PT content, whereas conductivity was not detected in the case of silver substrate manufacturing. The highest conductivity, as could be expected, was found for the composite with highest content of PT $(5.0 \%)$. The literature evidence suggests that such a conductivity value is promising for further investigations, that is, for this material's use in electrode preparation for DSSCs [31].

Table 4. Electric conductivity and fiber size of composites.

\begin{tabular}{cccc}
\hline Sample & Conductivity $(\mathbf{m S} / \mathbf{c m})$ & Particle Size in Solution $(\mathbf{n m})$ & Yarn Size $(\mathbf{n m})$ \\
\hline PAPT1Al & 29.4 & 23 & 184 \\
PAPT2Al & 11.9 & 23 & 179 \\
PAPT3Al & 8.7 & 23 & 171 \\
PAPT4Al & & 23 & 168 \\
PAPT5Al & 23 & 164 \\
PAPT6Al & 23 & 157 \\
PAPT7Al & 23 & 152 \\
PAPT1Ag & 23 & 185 \\
PAPT2Ag & 23 & 182 \\
PAPT3Ag & & 23 & 170 \\
PAPT4Ag & 23 & 162 \\
PAPT5Ag & & 23 & 160 \\
PAPT6Ag & 23 & 153 \\
PAPT7Ag & 23 & 149 \\
\hline
\end{tabular}

The particle size of PT, employed in composites manufacturing, was measured with dynamic light scattering in a formic acid solution at $25^{\circ} \mathrm{C}$. The results showed that composites had similar particle diameters in solution. The maximum difference was $3 \mathrm{~nm}$.

The morphological results are shown in Table 4, Figures 5 and 6. The SEM images presented in Figure 6 shows the surfaces of the polymer composites. The fiber diameter was averaged for 100 fibers from at least five micrographs. The composites had a three-dimensional network structure composed of randomly oriented polymer fibers. The composites prepared by electrospinning were analyzed via SEM and showed yarn sizes between $149 \mathrm{~nm}$ and $185 \mathrm{~nm}$, depending on PT content. The composite with 5\% PT content exhibited the biggest yarn sizes of 184 and $185 \mathrm{~nm}$ for PAPT1Al and PAPT1Ag, respectively. The composites with 3\% of PT were as follows: PAPT2Al showed the yarn size of 
$179 \mathrm{~nm}$ and PAPT2Ag $182 \mathrm{~nm}$. Composite PAPT3Al exhibited a yarn size of $171 \mathrm{~nm}$ and composite PAPT3Ag $170 \mathrm{~nm}$. Figure 5 shows the dependence between PT concentration in composite and yarn size. The analysis of results indicated that the yarn size decreased within decreasing PT concentration in composites. For example, the PAPT1Al composite showed a yarn size of $184 \mathrm{~nm}$ and PAPT7Al $152 \mathrm{~nm}$, and the composite PAPT1Ag showed a yarn size of $185 \mathrm{~nm}$ and PAPT7Ag $149 \mathrm{~nm}$.

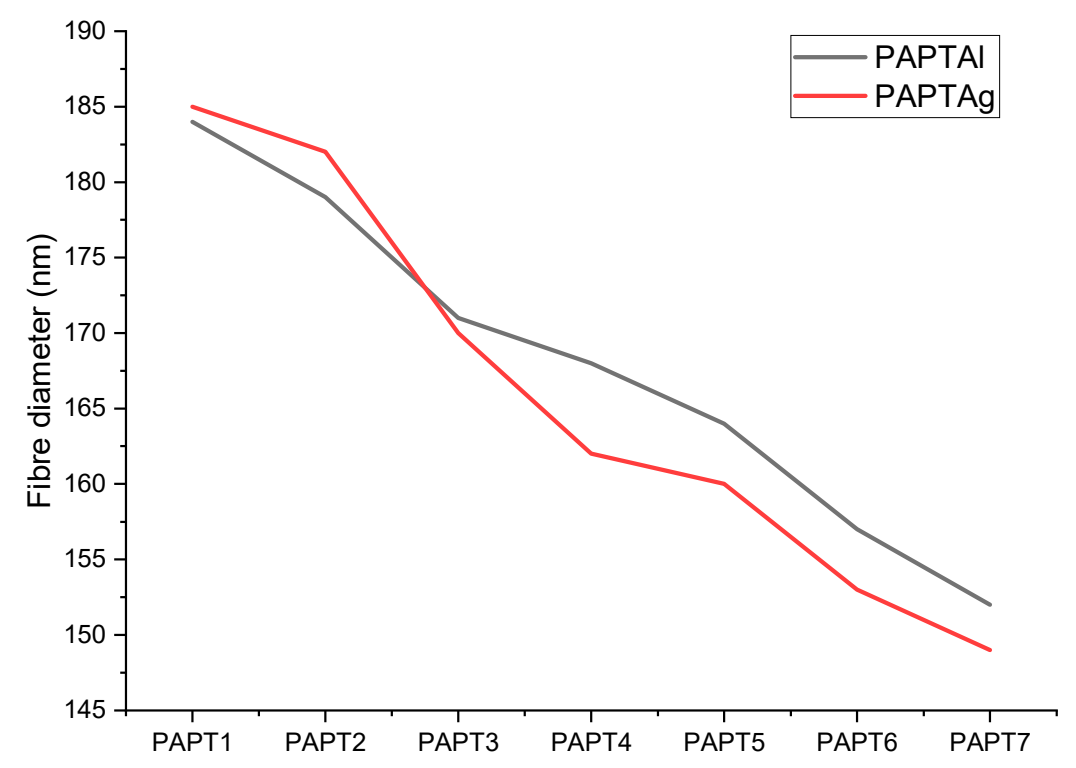

Figure 5. The fiber diameter of composites measured by SEM.

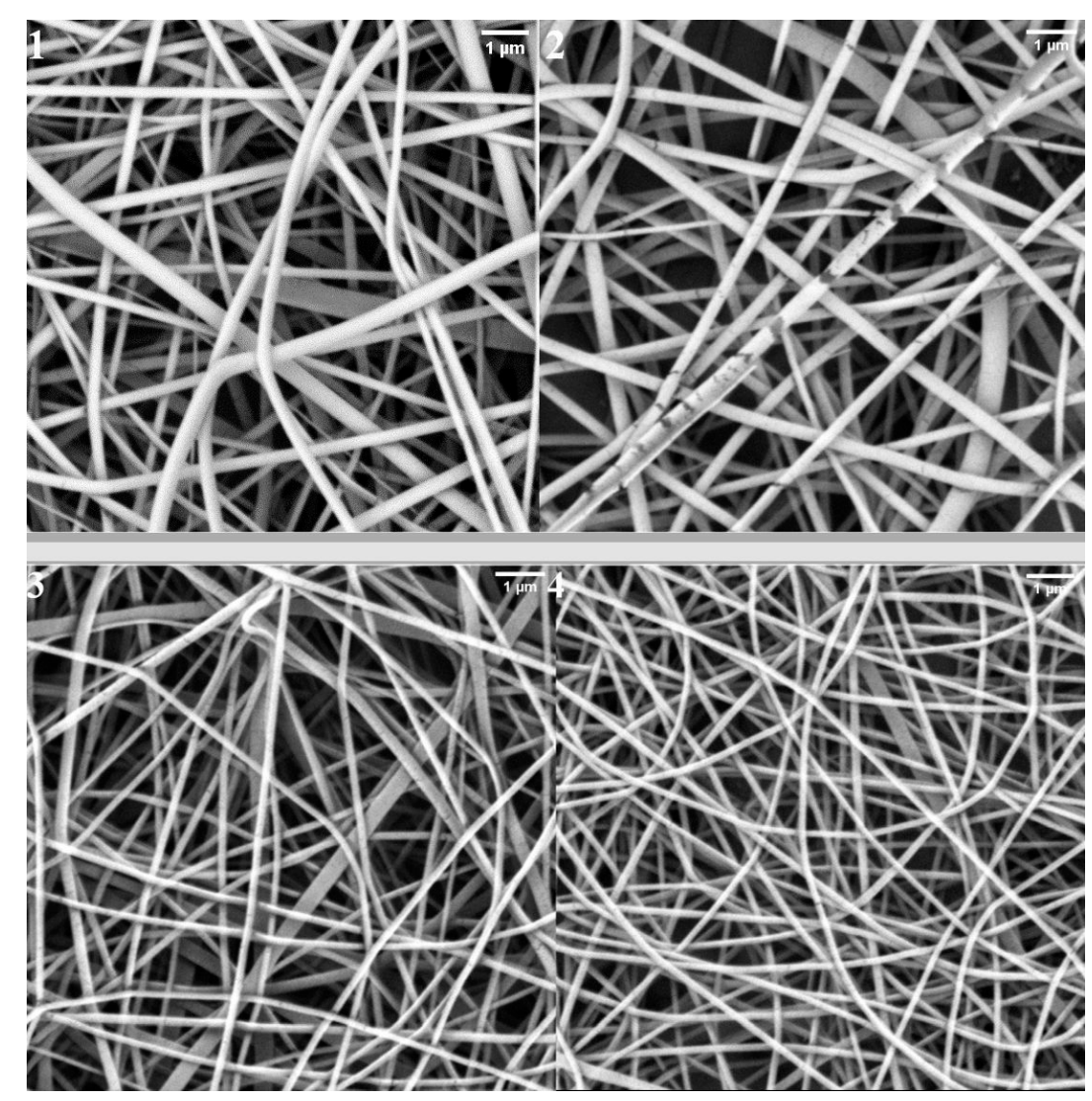

Figure 6. SEM micrographs of PAPT1Al (1), PAPT7Al (2), PAPT1Ag (3) and PAPT7Ag (4) composites. 
The yarn size was related to the conductivity of the composites; the higher the conductivity of the material, the greater the yarn size. Increasing the polyaniline content in the composite increased the formation of small agglomerates on fiber surfaces, which can be explained by the increasing conductivity of the composites. The yarn sizes were in agreement with the particle sizes determined by DLS in water.

\section{Materials and Methods}

\subsection{Materials}

Thiophene ( $\geq 99 \%$, Sigma-Aldrich, Saint Louis, MI, USA), anhydrous ferric chloride ( $\geq 99 \%$, Sigma-Aldrich, Saint Louis, MI, USA), polyamide 6 (Sigma-Aldrich, Saint Louis, MI, USA), formic acid (97\%, Sigma-Aldrich, Saint Louis, MI, USA) and methanol ( $\geq 99 \%$, Sigma-Aldrich, Saint Louis, MI, USA) were used as received. Chloroform was dried over phosphorus pentoxide under reflux and used immediately after distillation.

\subsection{Synthesis}

The synthesis was carried out via oxidative polymerization with anhydrous ferric chloride in dry chloroform. Polymer was synthesized at room temperature $\left(20^{\circ} \mathrm{C}\right)$ under argon atmosphere. Thiophene $(12 \mathrm{mmol})$ was added into a dispersion of ferric chloride $(48 \mathrm{mmol})$ of chloroform $(150 \mathrm{~mL})$. After $24 \mathrm{~h}$, the polymer was precipitated in methanol and filtered on filter paper. The obtained polymer was dissolved in chloroform and reprecipitated in methanol to be purified and was dried under reduced pressure. The reaction yield was $84 \%$.

\subsection{Electrospinning}

The solutions of composites were made by dissolving polythiophenepolythiophene (PT) $(1.53 \mathrm{~g})$ in polyamide (PA) $(6.70 \mathrm{~g})$ solution in formic acid $(30.50 \mathrm{~g} ; 25.00 \mathrm{~mL}, 18 \%)$. The solutions were mixed $2 \mathrm{~h}$ before the electrospinning process. The solution flow rate was $0.20 \mathrm{~mL} / \mathrm{h}$, the needle diameter was $0.5 \mathrm{~mm}$ and the voltage was $25 \mathrm{kV}$. The composites were prepared with $0.05 \%, 0.5 \%, 2 \%$ and $5 \%$ mass percent of polythiophene in solution by diluting the base solution. The solutions were electrospun on aluminum $(\mathrm{Al})$ and silver (Ag) round substrates. Table 1 represents the preparation and names of samples.

\subsection{Methods}

Thermogravimetric analysis (TGA) measurements were performed using a TGA 55 (TA Instruments, New Castle, DE, USA) device. Experiments were carried out in a nitrogen stream $(20 \mathrm{~mL} / \mathrm{min})$ with a scanning rate of $10^{\circ} \mathrm{C} / \mathrm{min}$ in the temperature range of 30-900 ${ }^{\circ} \mathrm{C}$. Differential scanning calorimetry (DSC) measurements were performed using a Q2000 calorimeter (TA Instruments, New Castle, DE, USA) in a nitrogen stream at a scanning rate of $20^{\circ} \mathrm{C} / \mathrm{min}$. Samples were analyzed in aluminum pans in the temperature range of -80 to $300^{\circ} \mathrm{C}$. Fourier transform infrared (FTIR) measurements were performed in the range of $4000-400 \mathrm{~cm}^{-1}$ with potassium bromide (KBr)-pressed pellets using a Spectrum One instrument (Perkin Elmer, New Castle, DE, USA). The samples were measured at room temperature, and pellets were prepared by mixing $10.0 \mathrm{mg}$ of polymer with $100.0 \mathrm{mg}$ of $\mathrm{KBr}$. The sample pellets were prepared by applying high pressure to a polymer sample with KBr. Scanning electron microscopy (SEM) measurements were performed using a scanning electron microscope (Quanta 250 FEG, FEI Company, New Castle, DE, USA) operating with an acceleration voltage of $10 \mathrm{kV}$ under low vacuum $(80 \mathrm{~Pa})$. Electron micrographs were obtained from secondary electrons collected by a large-field detector (LFD). The samples were stuck to microscopic stubs by double-sided adhesive carbon tape. Micrograph analysis was carried out using ImageJ software. Conductivity measurements were made using a two-point probe conductor using a Keithley 2400 multimeter. Sizes were determined with a Litesizer 500 (Anton Paar GmbH, Graz, Austria) equipped with a $658 \mathrm{~nm}$ laser. The measurements were carried out at $90^{\circ}$ in polystyrene cuvettes. Measurements were conducted 5 times at $25^{\circ} \mathrm{C}$ for $60 \mathrm{~s}$, with equilibration periods of $3 \mathrm{~min}$. 
Dynamic mechanical measurements were carried out on a DMTA Q800 (TA Instruments, New Castle, DE, USA) analyzer. DMTA allowed us to investigate the mechanical property behaviors related to Brownian motion of the polymer chains, such as variation in the mechanical modulus versus temperature. The mechanical dissipation factor, $\tan \delta$, as a measure of the deformational energy dissipated as heat during each cycle, is given by $\tan \delta=\mathrm{E}^{\prime \prime} / \mathrm{E}^{\prime}$. The storage modulus, loss modulus and tangent $\delta$ of the samples were determined at $1 \mathrm{~Hz}$ and from $-80^{\circ} \mathrm{C}$ to $220^{\circ} \mathrm{C}$ at a heating rate of $3{ }^{\circ} \mathrm{C} / \mathrm{min}$. The sample dimensions were $15.0 \mathrm{~mm} \times 4.0 \mathrm{~mm}$ in compression mode. TGA, DSC, IR as well as DMTA analyses were carried out using OriginPro 2019b.

\section{Conclusions}

Investigation of parameters of composites prepared using polythiophene and polyamide indicate the possible application of these materials in construction of DSSC and others. The mechanical parameters have to be taken into consideration when controlling the conductivity in manufacturing.

Author Contributions: Conceptualization, E.S.-B., K.B.; methodology, K.B., M.L., R.F., T.K.; validation, R.F., E.S.-B., M.L.; formal analysis, K.B., M.L.; investigation, K.B., T.K.; writing-original draft preparation, K.B., M.L.; writing-review and editing E.S.-B.; visualization, K.B.; supervision, R.F., E.S.-B.; funding acquisition E.S.-B. All authors have read and agreed to the published version of the manuscript.

Funding: This study was funded by the National Science Centre, grant number 2016/23/B/ST8/02045.

Institutional Review Board Statement: Not applicable.

Informed Consent Statement: Not applicable.

Data Availability Statement: The data presented in this study are available in this article.

Conflicts of Interest: The authors declare no conflict of interest.

Sample Availability: Samples of the compounds are available from the authors.

\section{References}

1. Sun, G.; Sun, L.; Xie, H.; Liu, J. Electrospinning of Nanofibres for Energy Applications. Nanomaterials 2016, 6, 129. [CrossRef] [PubMed]

2. Nagata, S.; Atkinson, G.M.; Pestov, D.; Tepper, G.C.; Mcleskey, J.T., Jr. Electrospun Polymer-Fibre Solar Cell. Adv. Mater. Sci. Eng. 2013, 2013, 975947. [CrossRef]

3. Li, Z.; Ye, B.; Hu, X.; Ma, X.; Zhang, X.; Deng, Y. Facile electropolymerized-PANI as counter electrode for low cost dye-sensitized solar cell. Electrochem. Comm. 2009, 11, 1768-1771. [CrossRef]

4. Ameen, S.; Akhtar, M.S.; Kim, G.S.; Kim, Y.S.; Yang, O.B.; Shin, H.S. Plasma-enhanced polymerized aniline $/ \mathrm{TiO}_{2}$ dye-sensitized solar cells. J. Alloys Compd. 2009, 487, 382-386. [CrossRef]

5. Shahid, M.U.; Mohamed, N.M.; Muhsan, A.S.; Bashiri, R.; Shamsudin, A.E.; Zaine, S.N.A. Few-layer graphene supported polyaniline (PANI) film as a transparent counter electrode for dye-sensitized solar cells. Diam. Relat. Mater. 2019, 94, 242-251. [CrossRef]

6. Stejskal, J.; Sapurina, I.; Prokes, J.; Zemek, J. In-situ polymerized polyaniline films. Synth. Met. 1999, 105, 195-202. [CrossRef]

7. MacDiarmid, A.G.; Chang, J.; Halpern, M.; Huang, W.; Mu, S.; Somasiri, N.; Wu, W.; Yangier, S. "Polyaniline": Interconversion of Metallic and Insulating Forms. Mol. Cryst. Liq. Cryst. 1985, 121, 173-180. [CrossRef]

8. Wu, J.; Lan, Z.; Lin, J.; Huang, M.; Huang, Y.; Fan, L.; Luo, G.; Lin, Y.; Xie, Y.; Wei, Y. Counter electrodes in dye-sensitized solar cells. Chem. Soc. Rev. 2017, 46, 5975-6023. [CrossRef]

9. McCullough, R.D. The chemistry of conducting polythiophenes. Adv. Mater. 1998, 10, 93-116. [CrossRef]

10. Yamamoto, T.; Sanechika, K.; Yamamoto, A. Preparation of thermostable and electric-conducting poly(2,5-thienylene). J. Polym. Sci. Polym. Lett. Ed. 1980, 18, 9-12. [CrossRef]

11. Yoshino, K.; Hayashi, S.; Sugimoto, R. Preparation and Properties of Conducting Heterocyclic Polymer Films by Chemical Method. J. Appl. Phys. 1984, 23, L899. [CrossRef]

12. Wu, S.J.; Tai, Q.D.; Yan, F. Hybrid Photovoltaic Devices Based on Poly (3-hexylthiophene) and Ordered Electrospun ZnO Nanofibers. J. Phys. Chem. C 2010, 114, 6197-6200. [CrossRef]

13. Laforgue, A.; Power, J. All-textile flexible supercapacitors using electrospun poly(3,4-ethylenedioxythiophene) nanofibers. Sources 2011, 196, 559-564. [CrossRef] 
14. Yarin, A.L.; Pourdeyhimi, B.; Ramakrishna, S. Fundamentals and Applications of Micro- and Nanofibers; Cambridge University Press: Cambridge, UK, 2014.

15. Yarin, A.L. Coaxial electrospinning and emulsion electrospinning of core-shell fibers. Polym. Adv. Technol. 2011, 22, 310-317. [CrossRef]

16. Reneker, D.H.; Yarin, A.L.; Fong, H.; Koombhongse, S. Bending instability of electrically charged liquid jets of polymer solutions in electrospinning. J. Appl. Phys. 2000, 87, 4531. [CrossRef]

17. Chen, J.Y.; Kuo, C.C.; Lai, C.S.; Chen, W.C.; Chen, H.L. Manipulation on the Morphology and Electrical Properties of Aligned Electrospun Nanofibers of Poly(3-hexylthiophene) for Field-Effect Transistor Applications. Macromolecules 2011, 44, $2883-2892$. [CrossRef]

18. Raeesi, F.; Nouri, M.; Haghi, K. Electrospinning of polyaniline-polyacrylonitrile blend nanofibers. e-Polymers 2009, 114, 1-13. [CrossRef]

19. Baştürk, E.; Çakmakçi, E.; Madakba, S.; Kahraman, M. Surface and proton conductivity properties of electrospun poly(vinyl butyral).polyaniline nanofibers. Adv. Polym. Technol. 2018, 37, 1774-1781. [CrossRef]

20. Kajal, G.; Aniruddha, C.; Praveen, G.; Snigdha, S.; Sudeep, R.; Christian, A.; Sabu, T.; Ivo, P. Electrospinning over Solvent Casting: Tuning of Mechanical Properties of Membranes. Sci. Rep. 2018, 8, 5058.

21. Ahmed, F.; Kumar, S.; Arshi, N.; Anwar, M.S.; Su-Yeon, L.; Kil, G.-S.; Park, D.-W.; Koo, B.H.; Lee, C.G. Preparation and characterizations of polyaniline (PANI)/ZnO nanocomposites film using solution casting method. Thin Solid Films 2011, 519, 8375-8378. [CrossRef]

22. Ryu, H.W.; Kim, Y.S.; Kim, J.H.; Cheong, I.W. Direct synthetic route for water-dispersible polythiophene nanoparticles via surfactant-free oxidative polymerization. Polymer 2014, 3, 806-812. [CrossRef]

23. Alakhras, F.; Holze, R. In situ UV-vis- and FT-IR-spectroscopy of electrochemically synthesized furan-thiophene copolymers. Synth. Met. 2007, 2, 109-119. [CrossRef]

24. Liu, R.; Liu, Z. Polythiophene: Synthesis in aqueous medium and controllable morphology. Chin. Sci. Bull. 2009, 12, 2028-2932. [CrossRef]

25. Fissan, H.; Ristig, S.; Kaminski, H.; Asbach, C.H.; Epple, M. Comparison of different characterization methods for nanoparticle dispersions before and after aerosolization. Anal. Met. 2014, 6, 7324-7334. [CrossRef]

26. Pashaei, S.; Siddaramaich, S.P.; Avval, M.M.; Syed, A.A. Thermal degradation kinetics of nylon6/GF/crysnano nanoclay nanocomposites by TGA. Chem. Ind. Chem. Eng. Q. 2011, 17, 141-151. [CrossRef]

27. Zhao, M.; Yi, D.; Camino, G.; Frache, A.; Yang, R. Interdigitated crystalline MMT-MCA in polyamide 6. RSC Adv. 2017, 7, 861-869. [CrossRef]

28. Parodi, E.; Govaert, L.E.; Peters, G.W.M. Glass transition temperature versus structure of polyamide 6: A flash-DSC study. Thermochim. Acta 2017, 657, 110-122. [CrossRef]

29. Howard, W.H. The glass temperatures of polyacrylonitrile and acrylonitrile-vinyl acetate copolymers. J. Appl. Polym. Sci. 1961, 5, 303-307. [CrossRef]

30. Otaegi, I.; Aramburu, N.; Muller, A.; Guerrica-Echevarria, G. Novel Biobased Polyamide 410/Polyamide 6/CNT Nanocomposites. Polymers 2018, 10, 986. [CrossRef]

31. Beevers, R.B. Dependence of the glass transition temperature of polyacrylonitrile on molecular weight. J. Polym. Sci. Part A 1964, 2, 5257-5265. [CrossRef] 